E3S Web of Conferences 1, 03006 (2013)

DOI: $10.1051 / \mathrm{e} 3$ sconf/20130103006

(C) Owned by the authors, published by EDP Sciences, 2013

\title{
Size-segregated concentration of heavy metals in an urban aerosol of the Balkans region (Belgrade)
}

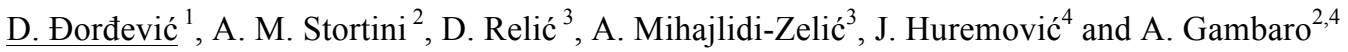 \\ ${ }^{1}$ ICTM - Centre of Chemistry, University of Belgrade, Studentski trg 12-16, 11000 Belgrade, Serbia, \\ dragadj@chem.bg.ac.rs \\ ${ }^{2}$ Institute for the Dynamics of Environmental Processes (CNR-IDPA), Calle Larga Santa Marta 2137, 30123, Venice, \\ stortini@unive.it \\ ${ }^{3}$ Faculty of Chemistry, University of Belgrade, Studentski trg 12-16, 11000 Belgrade, Serbia, dradman@chem.bg.ac.rs, \\ amzelic@chem.bg.ac.rs \\ ${ }^{4}$ Faculties of Science, Department of Chemistry, University of Sarajevo, 71000 Sarajevo, Bosnia and Herzegovina, \\ jasnahuremovic@yahoo.com \\ ${ }^{5}$ Environmental Sciences, Informatics, Statistic Department, Ca' Foscari University of Venice, Calle Larga Santa Marta \\ 2137, 30123 Venice, Italy, gambaro@unive.it
}

\begin{abstract}
This work focuses on the heavy metals contents of the size-segregated urban aerosol of the continental area of Balkans. The distribution of nano/micron heavy metals in the size-segregated urban aerosol of Belgrade center was studied during the summer-autumn of 2008. The particle size distribution in the size ranges $D_{\mathrm{p}} \leq 0.49 \mu \mathrm{m}, 0.49 \leq D_{\mathrm{p}} \leq 0.95 \mu \mathrm{m}, 0.95 \leq D_{\mathrm{p}} \leq 1.5 \mu \mathrm{m}, 1.5 \leq D_{\mathrm{p}} \leq 3.0 \mu \mathrm{m}, 3.0 \leq D_{\mathrm{p}} \leq 7.2 \mu \mathrm{m}$ and $D_{\mathrm{p}} \geq 7.2 \mu \mathrm{m}$ was measured. The aerosol samples were submitted to gravimetric and chemical analyses. The obtained mean mass concentration of the PM fractions was in accordance with an urban aerosol distribution. The aerosol mass concentrations were determined by gravimetric measurements $\left(m_{\mathrm{GM}}\right)$ and, for heavy metals analyzed by ICP/MS.
\end{abstract}

Key words: Heavy metals, urban aerosol, Balkan

\section{Introduction}

Tropospheric aerosols contain crustal and trace elements. A significant fraction of the tropospheric aerosol is anthropogenic in origin. Emissions of particulate matter attributable to the human activities arise primarily from four source categories: fuel combustion, industrial processes, and nonindustrial fugitive sources (roadway dust from paved and unpaved roads, wind erosion of cropland, construction etc.) and transportation sources (Seinfeld and Pandis, 1998).

An atmospheric aerosol is generally a mixture of species from a number of sources.

Heavy metals are natural constituents of the Earth crust. A number of these elements are biologically essential and are introduced into aquatic environments by various anthropogenic activities. Main anthropogenic sources of heavy metals exist in various industrial point sources, e.g. present and former mining activities, foundries, smelters and diffuse sources such as piping, constituents of products, combustion by-products, traffic, industrial and human activities (Al-Khashman, 2004).
Heavy metal emissions from road transport, specifically cadmium, chrome, nickel, lead and arsenic, are the cause for ambient concentrations that can lead to not only environmental damage but also to a variety of adverse health effects such as the damage of body organs and cancer (Kumer et al., 2009).

\section{Materials and Methods}

Size-segregated aerosol was sampled during the June December 2008 period. The sampling site $\left(44^{0} 49^{\prime} 14^{\prime}\right.$ ' $N$, $\left.20^{0} 27^{\prime} 44^{\prime \prime} \mathrm{E}\right)$ was urban located in the city center of Belgrade (Fig. 1). In the vicinity of the sampling site at the distance of about $100 \mathrm{~m}$ the terminus of trolleybuses is located. Between sampling site and the terminus of trolleybuses are the park and the low frequency road. Coal Fired Power Plant Nikola Tesla A and B (Obrenovac) is located about $45 \mathrm{~km}$ south-west and Pančevo industrial city is about $15 \mathrm{~km}$ east of Belgrade.

During the measurement campaign, 32 sample sets were taken every 6 th day. The sampling duration for each sample set was 48 hours. Each sample set comprised six 
atmospheric aerosol samples in the following particle size ranges: $D_{p} \leq 0.49 \mu \mathrm{m}, 0.49 \leq D_{p} \leq 0.95 \mu \mathrm{m}, 0.95 \leq D_{p} \leq$ $1.5 \mu \mathrm{m}, 1.5 \leq D_{p} \leq 3.0 \mu \mathrm{m}, 3.0 \leq D_{p} \leq 7.2 \mu \mathrm{m}$ and $D_{p} \geq$ $7.2 \mu \mathrm{m}$.

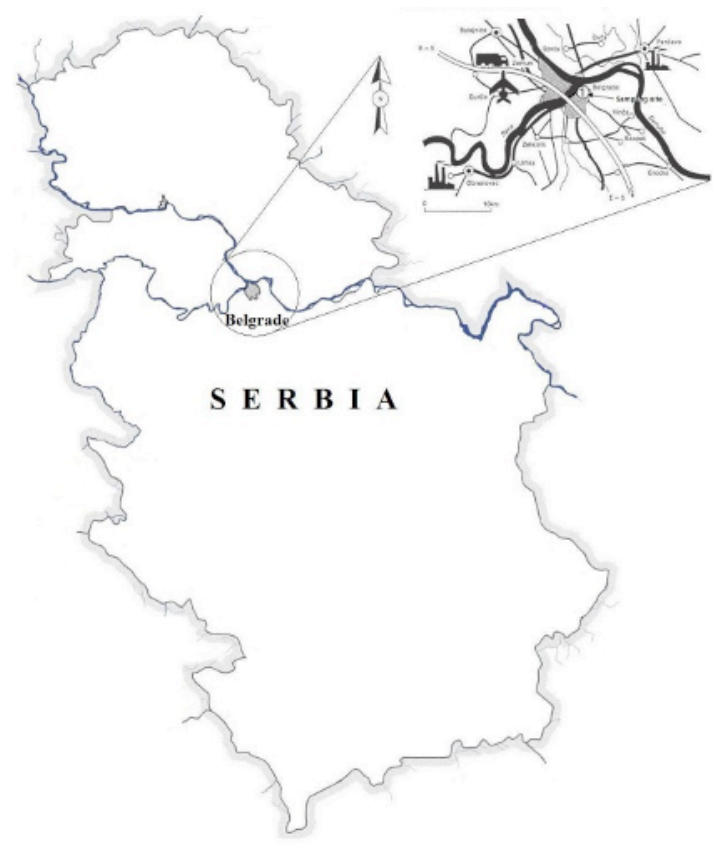

Fig. 1. Sampling site

Aerosol mass concentrations are determined by gravimetric measurements $\left(\mathrm{m}_{\mathrm{GM}}\right)$. Blank and sample filters were weighed three times over $24 \mathrm{~h}$ before and after the sampling using a KERN ABT 120-5DM Balance (Accuracy class I and precision of $0.01 \mathrm{mg}$ ). The balance and the filters were kept in a temperature $\left(20 \pm 5^{\circ} \mathrm{C}\right)$ and humidity $(45 \pm 5 \%)$ controlled nitrogen glove box before and during the weighing procedure. Each filter was microwave digested (Ethos1-Milestone) inside a Teflon vessel $(100 \mathrm{ml})$, using the mixture of acids $\left(\mathrm{HNO}_{3}, \mathrm{H}_{2} \mathrm{O}_{2}\right.$ and HF). Trace elements in the fractions of particles samples were measured by Inductively Coupled Plasma-Quadrupole Mass Spectrometry (ICP-QMS Agilent 7500I), the accuracy and precision of the method was controlled using the standard reference material (Urban Particulate Matter NIST 1684). Elements concentrations in samples have been obtained after subtraction of their field blank values (Stortini et al. 2009).

\section{Results and Discussion}

The particle mass distributions and chemical analysis of heavy metals in six stages were measured. The mean mass concentration of the PM fractions showed two maximums: first in the fine mode range $0.49 \leqslant D_{p} \leqslant$ $0.95 \mu \mathrm{m}$ and the second in the coarse mode $D_{p} \geqslant 7.2$ $\mu \mathrm{m}$, which is in accordance with the distribution of an urban aerosol. The size distributions of heavy metals consist of average values obtained in the measured campaign. In this study, a simple bi-modal aerosol size distribution with two modes, $\left(D_{p}<1.5 \mu \mathrm{m}\right.$ and $D_{p}>1.5$ $\mu \mathrm{m})$ for crustal elements (Al, Fe, Mn, Cr, Ga, Co) and for $\mathrm{Bi}, \mathrm{Pb}, \mathrm{Sb}$ and $\mathrm{Cu}$ was considered (Fig. 2). However $\mathrm{V}$, $\mathrm{Ni}, \mathrm{Zn}, \mathrm{Cd}$ and $\mathrm{As}$ had a dominant mode in the range of the fine particles $\left(D_{p}<1.5 \mu \mathrm{m}\right)$. The obtained results show that the absolute highest concentration was found for $\mathrm{Fe}\left(104.8 \pm 59.5 \mathrm{ng} \mathrm{m}^{-3}\right)$ in the size range $3.0 \leqslant D_{p} \leqslant$ $7.2 \mu \mathrm{m}$. Also, significant values of concentration in the same size range was found for $\mathrm{Al}\left(65.4 \pm 45.6 \mathrm{ng} \mathrm{m}^{-3}\right)$. On the other hand, the high average concentrations of $\mathrm{Zn}$ $\left(28.2 \pm 26.2 \mathrm{ng} \mathrm{m}^{-3}\right), \mathrm{V}\left(2.6 \pm 2.4 \mathrm{ng} \mathrm{m}^{-3}\right), \mathrm{Ni}(1.1 \pm 1.0$ $\left.\mathrm{ng} \mathrm{m}^{-3}\right)$, As $\left(1.2 \pm 1.1 \mathrm{ng} \mathrm{m}^{-3}\right)$ and $\mathrm{Cd}\left(0.2 \pm 0.2 \mathrm{ng} \mathrm{m}^{-3}\right)$ were found in the size range $D_{p}<0.49 \mu \mathrm{m}$.

Distributions of heavy metals concentrations given in time series (Fig. 3) showed the domination of $\mathrm{Zn}, \mathrm{V}$, $\mathrm{Ni}$, As and $\mathrm{Cd}$ in the fine mode, while heavy metals originating in mechanical processes dominated in the coarse particles, such as $\mathrm{Al}, \mathrm{Fe}, \mathrm{Mn}, \mathrm{Cr}, \mathrm{Ga}, \mathrm{Co}, \mathrm{Cu}$.

The heavy metals present in the fine mode largely originate from anthropogenic activities like traffic or/and burning of fosil fuels in industrial and domestic furnances. Peaks of these elements in fine mode are more intensive in autumn and winter which can be connected to the heating season.

On the south west direction of Belgrade at a distance of about $45 \mathrm{~km}$ Coal Fired Power Plant (Fig. 1) that is using lignite with high content of As is located. On the other hand in the north east segment at the distance of 15 $\mathrm{km}$ of Belgrade there is industrial city of Pančevo. In industrial zone of Pančevo city there are oil refinery, pethrochemical plant and fertilizer plant. $\mathrm{V}$ and $\mathrm{Ni}$ are tracers of oil refinery.

Trafic could be identified by $\mathrm{Pb}$.

Simultaneous maximum concentrations for $\mathrm{Fe}, \mathrm{Mn}$, $\mathrm{Cr}, \mathrm{Ga}, \mathrm{Cu}$ presented as sharp peaks on Fig. 3 indicate their common origin, most likely re-suspension as well as long range transport from desert dust (most probably Sahara or volacanoes in south east Italy like Etna and Vesuvius) since south west air masess are one of prevailing in the central Balkans region. The most prevailing air mases are from the north west segment. 

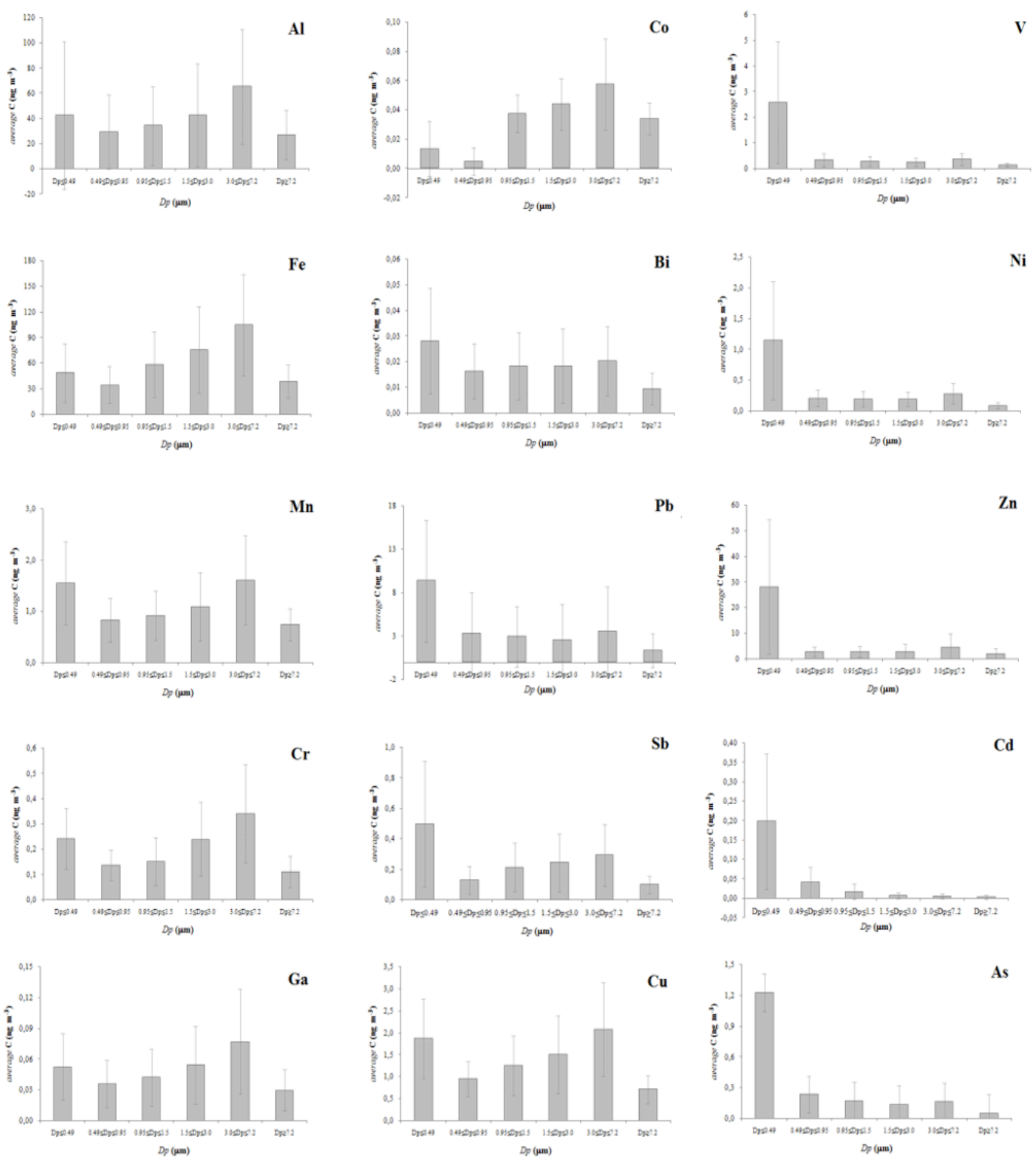

Fig. 2. Average concentrations including standard deviations distributed through $D_{p}$ intervals. 

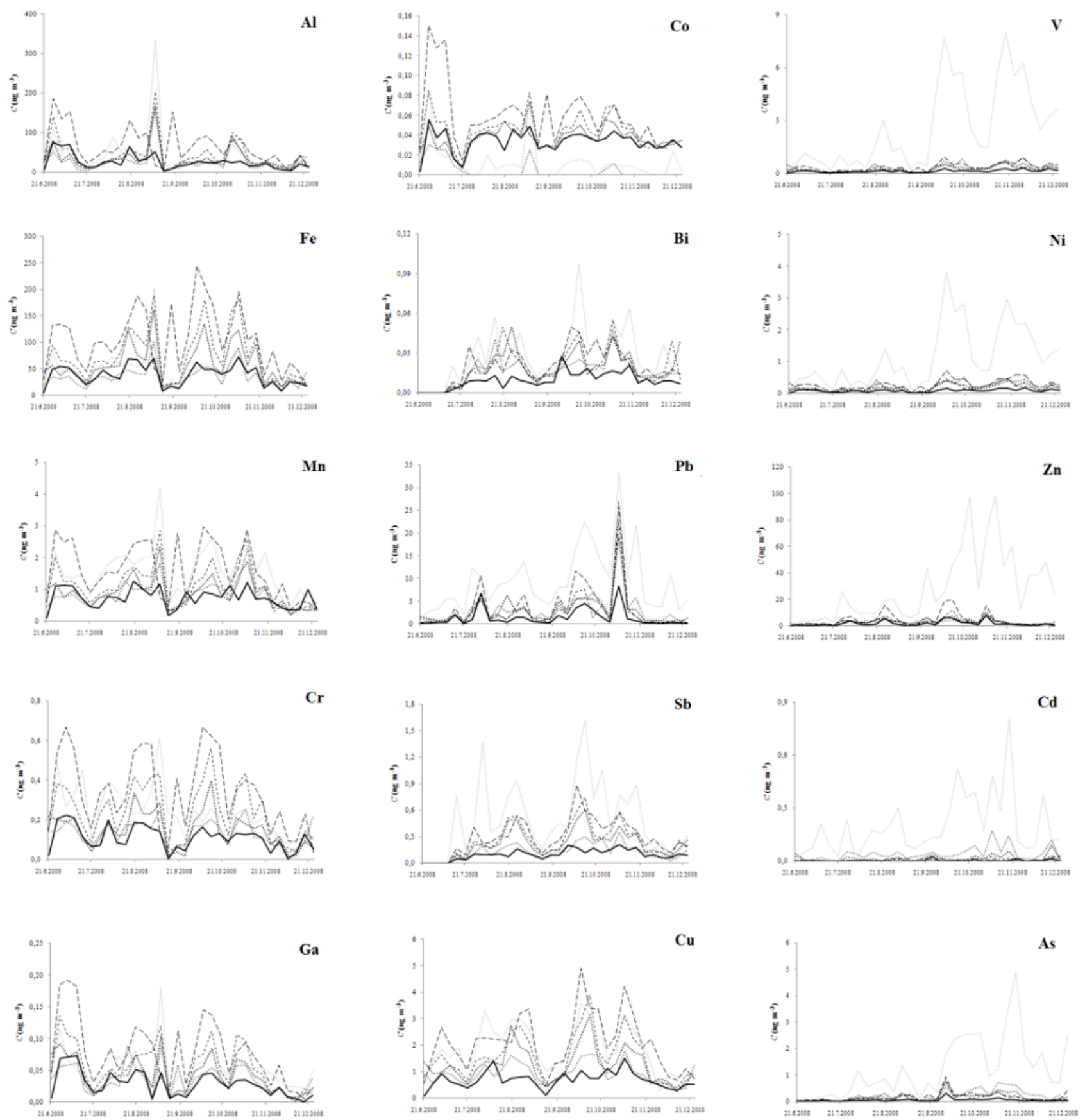

$0 p \$ 0.49 \mu \mathrm{m}$
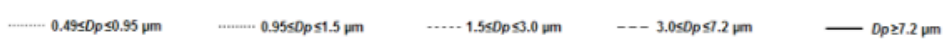

Fig. 3. Time series of heavy metals concentrations through $D_{p}$ intervals.

\section{Conclusion}

Aerosol size distributions measurements of the urban aerosol in the continental part of the Balkan Peninsula showed As, $\mathrm{Cd}, \mathrm{Ni}, \mathrm{V}$ and $\mathrm{Zn}$ in the fine mode as a markers for burning processes, while heavy metals: Al, $\mathrm{Fe}, \mathrm{Mn}, \mathrm{Cr}, \mathrm{Ga}, \mathrm{Co}, \mathrm{Cu}$ originating from mechanical processes (like re-suspension, long range transport from remote areas, reconstruction activities etc.) dominated in the coarse particles.

\section{Acknowledgements}

The authors thank the financial supports providing from the SIMCA project INTERREG/ CARDS-PHARE Adriatic New Neighborhood Programme, Grant No. 06SER02/01/04. The authors are also grateful to Ministry of education and science Republic of Serbia for the financial support of project 172001.

\section{References}

Seinfeld JH, Pandis SN (1998) Atmospheric Chemistry and Physics: From Air Pollution to Climate Change, 
John Wiley \& Sons, Inc, New York, pp. 363-381

Al-Khashman OA, Heavy metal distribution in dust,street dust and soils from the work place in Karak Industrial Estate, Jordan Atmospheric Environment 38 (2004) 6803-6812

Kummer U., Pacyna J., Pacyna E., Friedrich R., Assessment of heavy metal releases from the use phase of road transport in Europe Atmospheric
Environment 43 (2009) 640-647

Stortini, A. M., Freda, A., Cesari, D., Cairns, W. R. L., Contini, D., Barbante, C., Prodi, F., Cescon, P., Gambaro, A., 2009. An evaluation of the PM2.5 trace elemental composition in the Venice lagoon area and an analysis of the possible sources. Atmospheric Environment 43, 6296-6304. 